\title{
Sosyal Ağlarda Sanal Kimlik Kullanımının İncelenmesi
}

\author{
Examining The Use of Virtual Identity in Social Networks
}

Esra Barut Tuğtekin, Dr., İn̈nü Üniversitesi Uzaktan Eğitim Araştırma ve Uygulama Merkezi, E-posta: esra.barut@inonu.edu.tr Özcan Özgür Dursun, Doç. Dr., Anadolu Üniversitesi Eğitim Fakültesi, E-posta: oodursun@anadolu.edu.tr

https://doi.org/10.47998/ikad.900821

Anahtar Kelimeler:

Sanal Kimlik, Onay Bağımlılı̆̆1, Sosyal Ağlar.

\section{Keywords:}

Virtual Identity, Approval Dependence, Social Networks.
Öz

Sanal kimlikler; bireylerin, tercihleri doğrultusunda yapılandırarak oluşturdukları dijital kimlikleridir. Bu kimlikler sosyal ağ ortamındaki her davranışı açıklamak için kullanılabilecek bir potansiyele sahiptir ve paylaşım, beğeni, gizlilik ve güvenlik olmak üzere dört başlık çerçevesinde incelenmiştir. Sanal kimliğini kullanan birey, sanal dünyada kabul edilebilmek için toplumun genel normlarıyla tutarlı bir görünüm sergilemeyi tercih edebilir. Bu tercih ise sosyal ağlardaki sanal kimlik profillerini, sosyal ağ kullanım amaçlarının yanı sıra kabul görme ve onaylanma isteği doğrultusunda düzenlemeyi tetiklemektedir. Dolayısıyla sosyal ağlardaki sanal kimliklerin onay bağımlılığı ve sosyal ağ kullanım amaçlarıyla nasıl bir ilişki içerisinde olduğu bu araştırmanın odağını oluşturmaktadır. Bu araştırma, sosyal ağlar üzerinden katılım sağlayan 577 katılımcıyla gerçekleştirilmiştir. Araştırma sonuçlarına göre sosyal ağ kullanım amacı, sanal kimlik profilleri ve onay bağımlılı̆̆ının ortalamanın üzerinde göstergeleri bulunurken; kullanım amaçlarında iletişimin, sanal kimlik kullanımında ise paylaşımın öne çıktığı görülmektedir. Sosyal ağlardaki sanal kimliklerde erkeklerin gizlilik boyutuna, kadınların ise güvenlik boyutuna daha çok dikkat ettiği görülmüştür. Ayrıca sosyal ağ kullanım amaçları, onay bağımlılığı ve sanal kimlik profilleri birbirleriyle orta düzeyde anlamlı ilişkilere sahiptir. 


\section{Giriș}

Sosyal onay, bireyin, sosyal yaşama uyum sağlarken, başkalarının beklentilerini önemseyerek davranışlarına yön vermesiyle ilgili bir durumdur. Onaylanma beklentisi, doğuştan gelen kabul görme veya tasdik edilme gibi, kişisel bir gereksinim olarak bireyin tüm yaşamı boyunca kendini gösterebilmektedir. Onaylanma beklentisi, sosyalleşmeyi artıran bir durum olmakla birlikte; bireyin kendinden daha çok başkalarının isteklerine önem vermesi ve başkalarına göre yaşamını şekillendirmesine yol açabilecek de bir durumdur (Burns, 2006; Karaşar ve Öğütülmüş, 2016). Dolayısıyla başlangıçta haz veren bu beklenti sonrasında başkaları için yaşamaya, onaylanmak için davranış sergilemeye de dönüşebilir. Onaylanma gereksinimi Maslow'un (1943) ihtiyaç hiyerarşisinde yer alan önemli basamaklardan biri olarak kendini göstermektedir. Maslow'a göre insanlar yaşamlarını bazı ihtiyaçlar çerçevesinde yönetirler. Hedeflere ulaşabilmek için bu ihtiyaçların doyurulması gerekmektedir. Bu ihtiyaçlar genel olarak fiziksel, güvenlik, ait olma-sevgi, değer-saygınlık ve kendini gerçekleştirme basamaklarından oluşmaktadır. Bireyler kendini gerçekleştirme basamağına ulaşabilme hedefiyle diğer basamaklardaki ihtiyaçları tamamlamaya çalışmaktadırlar. Onay bağımlılı̆̆ı ise Maslow'un ihtiyaçlar hiyerarşisindeki sevgi-ait olma ile değer-saygınlık basamaklarında kendine yer bulmaktadır. Öyle ki ait olma ve sevgi basamağında başkaları ile iletişim kurma, başkaları tarafından kabul görme, bir gruba ait olma ihtiyaçları onaylanma ihtiyaçları ile benzerlik göstermektedir. Bunun yanında; değer ve saygınlık basamağında ise başarılı olma, başkaları tarafından takdir edilme, kabul edilme, benimsenme ihtiyaçları da onaylanma ihtiyacının doyurulma nedenleri olarak kendini göstermektedir. Bireylerin mutlu bir yaşam sürmesinde kendini gerçekleştirmeyi hedefleyenlerin yaşam döngülerinde ait olmasevgi ve değer-saygınlık ihtiyaçları göz önüne alındığında kontrol edilebilir seviyedeki onaylanma ihtiyacının her birey için normal bir durum olduğu söylenebilir. Diğer taraftan onaylanma ihtiyacının yaşamın geneline yayılması, bir türlü tatmin edilemiyor olması, onay olmaksızın davranış sergilenememesi gibi yoğunluğunun ve şiddetinin arttığı durumlarda ise bağımlılık durumu ortaya çıkmaktadır. Alanyazında onay bağımlılığı olarak kabul gören bu durum; bireylerin başkalarından olumlu geribildirim almaya, onaylanmaya ve kabul görmeye ilişkin aşırı duyarlılık göstermeleri olarak tanımlanmaktadır (Burns, 2006).

İnsanlar gerçek yaşam akışında onaylanma ihtiyacı hissedebilmektedirler. Sosyal ağların kullanımının küreselleşmesiyle birlikte birbirleriyle etkileşim içerisinde olan kullanıcılar sanal dünyalarda da onaylanma ihtiyacı içerisine girebilmektedirler (Leskovec vd., 2010). Sosyal ağlar günümüz internet kullanıcılarının en yoğun kullandığı ortamlar olarak karşımıza çıkmaktadır. Dolayısıyla sanal ortamdaki onay gereksiniminin de yoğun olarak sosyal ağlarda karşılandığı söylenebilir. Sosyal ağ sitelerinde onay amaçlı olarak çeşitli yardımcı araçlar sunulmaktadır. Beğenme, paylaşma, beğenmeme, reddetme, takip etme, takipten çıkarma, yorum yazma gibi seçenekler yardımıyla sanal ortamdaki profillerinin onaylanıp onaylanmadığına yönelik geribildirim alabilmektedirler. Sosyal ağlardaki onaylanma durumunun bir diğer göstergesi ise takipçi veya arkadaş sayısı olarak düşünülebilir. Kullanıcıların sosyal ağlardaki davranışları, takipçi/arkadaş sayısını artırdıkça o davranışların tekrarlanma olasılığı da artmaktadır. Dolayısıyla onay, bir bakıma sosyal ağdaki profilinin geribildirimi olarak görülmektedir. Onaylanma ihtiyacının 
sosyal ağlarda kendine yer bulması ait olma ve sevgi ihtiyacının da ötesine geçmektedir. Özellikle sosyal ağların yoğun kullanımıyla değer ve saygı ihtiyacını karşılamak için popülerleşme ve ün sahibi olma öne çıkan beklentiler arasında yer almıştır. Bireyin sosyal ağ ortamındaki popülaritesi (fenomen) değer ve saygıyla doğrudan ilişkilendirileceği için onay bağımlılığına yol açabilecek bir durumdur. Onay bağımlılığının sosyal ağlarda ortaya çıkışı, bireylerin arzuladığ için onaylanabileceği paylaşımlar yapmasına neden olabilmektedir. Bu durum zamanla bireylerin sosyal ağlarda sadece onay alabileceği davranışlar sergilemelerine ve onay bağımlısı olmalarına da yol açabilmektedir. Sosyal ağ kullanıcılarının onay bağımlısı olmalarında sosyal ağ kullanım amacı önemli bir faktör olabilmektedir. Bireylerin sosyal ağ kullanım amacına göre onaylanma ihtiyacının artabileceği veya azalabileceği ve bu doğrultuda paylaşımlara yön verilebileceği düşünülmektedir. Alanyazında sosyal ağ kullanım amacına yönelik farklı sınıflamalar yer almaktadır. İletişim başlatma ve sürdürme, araştırma sosyal etkinlik planlama ve eğlence amaçlı kullanım (Usluel vd., 2014), sosyal yaşam, iletişim ve eğitim amaçlı (Atıcı ve Çevik Polat, 2010) olarak sosyal ağ kullanımları sınıflandırılabilmektedir. Ayrıca sosyal ağ kullanım amaçları siyasal gelişim ve etkileşim, siyasal duyurum, siyasal gündem takibi gibi siyasal amaçlı (Arklan, 2016), ürün geliştirme ve tüketici ilişkileri bağlamında ticari amaçlı (Karlı, 2010), tanıtım, markalaşma, bilgi arama, müşteri ilişkileri kurma amaçlı (Parveen vd., 2015), halkla ilişkiler ve reklamcılık bağlamında (Özdemir vd., 2014), eğlence, sosyalleşme, sosyal değer geliştirme, bilgilenme ve öğrenme amaçlı (Benson vd., 2015) kullanımlar olarak değerlendirilebilmektedir. Karal ve Kokoç (2010) ise sosyal ağ kullanım amacını üç ana başlıkta incelemiştir. Bunlar Tanıma ve tanınma amaçlı, Sosyal etkileşim/İletişim amaçlı ve Eğitim amaçlı kullanımdır. Sosyal ağ kullanım amaçları; bireylerin sosyal ağları kullanmaya teşvik eden unsurların belirlenmesi (Brandtzæg ve Heim, 2009), ne amaçla ve nasıl kullanıldığının ortaya çıkarılması için önem taşımaktadır (Çetin, 2009).

Sosyal ağlar hangi amaçla kullanılırsa kullanılsın yapılan tüm işler sosyal ağ profili olarak adlandırılan kişisel sayfalar üzerinde gerçekleştirilmektedir. Dolayısıyla kullanıcılar, yönetebildikleri profil sayfaları ile sosyal ağ etkinlikleri gerçekleştirirler. $\mathrm{Bu}$ sosyal ağ profilleri ise kullanılan sosyal ağın yapısına göre zaman zaman görünür zaman zaman anonim olabilmektedir. Benzer şekilde sosyal ağ profili gerçekle birebir örtüşen bilgilere dayanabileceği gibi gerçeğin tamamen değiştirilmiş ve sanallaşmış bir versiyonu da olabilir. Çevrimiçi sosyal ağlarda diğer kullanıcılarla etkileşime girmek, haber izlemek, oyun oynamak için kullanıcıların profil hesaplarıyla sosyal ağ uygulamalarına giriş yapmaları gerekmektedir. Kullanılan bu profil hesabı sanal kimliği oluşturmaktadır (Loreti vd., 2018). Dolayısıyla sosyal ağlarda gerçekle örtüşen ya da çelişen sanal kimlikler kullanılabilmektedir. Sanal Kimlik; bireylerin kendi tercih ve istekleri doğrultusunda yapılandırarak oluşturdukları dijital kimlikleridir (Dursun ve Barut, 2016). Sanal Kimlikler; Paylaşım, Beğeni, Gizlilik ve Güvenlik olmak üzere dört başlık altında incelenmiştir. Sosyal ağlar çerçevesinde Sanal Kimlik boyutları incelenirse; sosyal ağlardaki kullanıcıların düşünce ve isteklerini davranışa dönüştürerek diğer kullanıcılara gösterme biçimi "paylaşım" olarak adlandırılabilir. "Paylaşım"; sosyal ağlarda gösterilen içerik sunumu, üretimi ve davranışı ifade eden bir kavramdır. Bireylerin başkaları tarafından sevilme, kabul görme, takdir edilme hislerinin sanal 
dünyada gösterim biçimi "beğeni”dir. Bu açıdan "Beğeni” sosyal ağlardaki içeriklere olumlu tepki alma ve gösterme şekillerinden biridir. Sosyal ağ kullanıcılarının gerçek kimlik bilgilerinin ne kadarının başkaları tarafından görülmesini istemesiyle ilgili yaptığı tüm düzenlemeler "gizlilik" boyutunu oluşturmaktadır. "Gizlilik" sosyal ağ kullanıcılarının sanal kimliklerinin görünürlüğüyle ilgili bir kavramdır. "Güvenlik” ise; sosyal ağ kullanıcılarının kendilerini diğer bireylerden ve etik suçlamalardan koruma içgüdüsüyle dikkate aldıkları kurallar temelinde sanal kimliklerini kullanma şekilleri olarak ifade edilebilir. Dolayısıyla "güvenlik" kavramı ise; sanal kimliği korumaya yönelik yapılan düzenlemeleri içermektedir. Tüm bu boyutların Sanal Kimlik Profilleri'nin düzenlenmesinde etkili olduğu, yapılan çalışmalarla belirlenmiştir (Barut Tuğtekin ve Dursun, 2020). Buna göre sanal kimlikler bireylerin sunmak istediği bilgileri içerecek şekilde bu boyutlar çerçevesinde düzenlenerek sosyal ağ sitelerinde kullanılmaktadır. Sunulmak istenilen bu içerikler bireylerin gerçek kimlik bilgileri olabildiği gibi gerçek dış1, olması istenen, kabul gören, onaylanabilir özellikteki bir kimlik bilgisini de içerebilmektedir. Sosyal ağlarda kullanılan sanal kimlikler Goffman'ın (2016) dramaturji ve izlenim teorisiyle uyuşmaktadır. Goffman'ın (2016) bu teorisine göre bireylerin birden fazla kimlikleri bulunmakta ve duruma uygun olarak istedikleri kimliği kullanmaktadırlar. $\mathrm{Bu}$ teoriye göre bireyler çevrelerinden beğeni toplamak için iyi izlenimler birakmak istemektedirler. Çevrelerinden aldıkları geribildirimlerle kimliklerine yön vermektedirler. Aynı zamanda bu doğrultuda izlenim oluşturmaya yönelik benlik algısına sahiptirler. Goffman'ın (2016) teorisinde görüldüğü üzere kimlik sunumu önemli bir kavram olurken sosyal ağlardaki kimlik sunumu ise sanal kimliklerin arzu edilen şekilde yönetilmesi şeklinde kendini göstermektedir. Parsell'e (2008) göre ise, internet ortamında birer topluluk üyesi olarak kabul edilebilmek için idealize edilmiş kimlik bilgileri sunmanın ve toplumun genel norm değerleriyle özdeşleşen bir görünüm sergilemenin bireyler için önemli olduğu belirtilmektedir. Dolayısıyla sosyal ağlardaki sanal kimlik profilleri kabul görme ve onaylanma isteği doğrultusunda düzenlenebilmektedir. Diğer taraftan geniş yaş aralığında sosyal ağ kullanımının olduğu göz önüne alındığında yaşa göre farklı davranışlar sergilenebilmektedir. Bir diğer önemli değişken olan cinsiyetin sosyal ağ kullanımında farklılıklar oluşturması göz önüne alındığında (Çiftçi, 2018; Himmetoğlu ve Ayhan, 2021; Yaman ve Kavuncu, 2019; Tuğtekin vd., 2020), sosyal ağlardaki sanal kimliklerin cinsiyete göre incelenmesinin değerli olacağı düşünülmektedir. Sonuç olarak sosyal ağlardaki sanal kimliklerin onay bağımlılığı ve sosyal ağ kullanım amacı ile nasıl bir ilişki içerisinde olduğu araştırılması gereken bir konu olarak karşımıza çıkmaktadır. $\mathrm{Bu}$ araştırmanın amacı sosyal ă kullanıcılarının sanal kimlik profillerinin çeşitli değişkenler bağlamında incelenmesidir. $\mathrm{Bu}$ amaç doğrultusunda şu araştırma sorularına yanıt aranmaktadır; "Katılımcıların sanal kimlik profilleri, sosyal ağ kullanım amaçları ve onay bağımlılığı özellikleri nasıldır?", "Sosyal ağ kullanım amacı, onay bağımlılığı ve sanal kimlik profilleri cinsiyete göre farklılaşmakta mıdır?", "Sosyal ağ kullanım amac1, onay bağımlılı̆̆ı ve sanal kimlik profilleri yaş ile nasıl bir ilişki göstermektedir?" ve "Sosyal ağ kullanım amaçları ve onay bağımlılığı sanal kimlik profilini açıklamakta midir?". 


\section{Yöntem}

Sosyal ăg kullanıcılarının Sanal Kimlik Profilleri'ni çeşitli değişkenler bağlamında inceleyen bu araştırma ilişkisel tarama modeli çerçevesinde desenlenmiştir. Araştırma konusuna ilişkin betimlemeyi gerçekleştirmek amacıyla tarama araştırması yapılmıştır (Fraenkel ve Wallen, 2011).

Araştırmanın yapısına uygun olacağı düşünülerek veri toplama süreci; sosyal ağlar üzerinden paylaşılan çevrimiçi veri toplama aracı ile gerçekleştirilmiştir. Bu araştırmanın çalışma grubunu çevrimiçi katılım sağlayan 577 sosyal ağ kullanıcısı oluşturmaktadır. Araştırmaya sadece 18 yaşın üzerindeki katılımcılar dâhil edilmiştir. Katılımcıların \%41.6'sı kadın ( $\mathrm{n}=240)$ ve \%58.4'ü erkektir $(\mathrm{n}=337)$. Katılımcıların yaşları 18 ile 60 yaş arasında değişmektedir $(\overline{\mathrm{X}}=26.32, \mathrm{SS}=8.75)$.

Araştırma sorularının yanıtlanabilmesi için anket formu dijital bir veri toplama aracına dönüştürülmüştür. $\mathrm{Bu}$ anket formunda; demografik bilgiler, Sanal Kimlik Profilleri Belirleme Ölçeği (Barut Tuğtekin ve Dursun, 2020), Sosyal A ̆ Siteleri Kullanım Amacı Ölçeği (Karal ve Kokoç, 2010) ve Kişilerarası İlişki Boyutları Ölçeği'nin Onay Bağımlılığı boyutu (İmamoğlu ve Aydın, 2009) yer almaktadır. Sanal Kimlik Profilleri Belirleme Ölçeği; Paylaşım, Beğeni, Gizlilik ve Güvenlik olma üzere dört alt boyuttan oluşmaktadır. Ölçek 5'li likert yapıda olup, ölçekte toplam 23 madde yer almaktadır. Ölçeğin tümüne ait Cronbach Alfa iç tutarlılık katsayısı 0,93'tür. Sosyal Ağ Siteleri Kullanım Amacı Ölçeği; Sosyal etkileşim-İletişim amaçlı kullanım, Tanıma ve tanınma amaçlı kullanım ve Eğitim amaçlı kullanım olmak üzere üç alt boyuttan oluşmaktadır. Ölçek 5'li likert yapıda toplam 14 madde içermektedir. Ölçeğin Cronbach Alpha iç tutarlılık katsayısı 0.83 'tür. Onay Bağımlılığı boyutu ise 5'li likert yapıda 15 maddeden oluşmaktadır. Cronbach Alfa iç tutarlılık katsayısı ise 0.84 'tür.

Analizlere başlamadan önce her test istatistiği için ön şartlar incelenmiştir. Bir değişken üzerinde birden fazla test yapılan analizlerde 1.tip hata oranını ortadan kaldırmak için Bonferonni düzeltmesi yapılmıştır. Veriler incelendiğinde toplam puanları karşılaştırılacak olan örneklemlerin ilişkisiz olduğu görülmüştür. Bağımlı değişkenlere ilişkin ölçümlerin normal dağılımları incelenmiştir. Buna göre Sanal Kimlik Profilleri Belirleme Ölçeği ve alt boyutlarının, Sosyal Ağ Siteleri Kullanım Amacı Ölçeği ve alt boyutlarının ve Kişilerarası İlişki Boyutları Ölçeği'nin Onay Bağımlılığı boyutunun toplam puanlarının normalliklerine bakıldığında çarpıklık ve basıklık değerlerinin +1 ,1 aralığında olduğu görülmüştür. Değişkenlerin P-P, Q-Q ve histogram grafiklerinin normal dağılım eğrisi üzerinde yoğunlaştığı görülmüştür. Dolayısıyla değişkenlerin toplam puanlarının tek değişkenli normallik şartlarını sağladığına karar verilmiştir. Çok değişkenli normalliği incelemek için 3 ölçeğe yönelik Mahalonobis hesaplanmış ve uç değer sorunu yaşanmadığı görülmüştür (Çokluk, Şekercioğlu ve Büyüköztürk, 2012; Pallant, 2001; Tabachnick ve Fidell, 2007).

Veri toplama araciyla elde edilmiş olan veriler SPSS-22 istatistik programıla analiz edilmiştir. Analizlerde frekans ölçümü, bağımsız gruplar t testi, korelasyon ve regresyon testi teknikleri kullanılmıştır. 


\section{Bulgular}

Araştırmanın "Katılımcıların sanal kimlik profilleri sosyal ağ kullanım amaçları ve onay bağımlılı̆̆ özellikleri nasıldır?" sorusunu yanıtlayabilme amacıyla yapılan betimsel analiz bulguları Tablo 1'de yer almaktadır.

Tablo 1 incelendiğinde tüm değişkenlerin ortalama toplam puanlarının ölçeklerin ortalama puanının üzerinde olduğu görülmektedir. Sosyal ağ kullanım amacına göre en çok İletişim ve Eğitim amaçlı kullanımların, sanal kimlik kullanım özelliklerinden en çok Paylaşım boyutunun, ayrıca Onay Bağımlılı̆̆ değişkeninin de ortalama puanlarının genel ortalamanın çok üzerinde olduğu anlaşılmaktadır. Değişkenlerin çarpıklık ve basıklık değerleri +1 ile -1 aralığında olup tek değişkenli normal dağılım göstermektedir. Dolayısıyla incelenen değişkenlerin normal dağılıma sahip olduğu belirlendiğinden veri seti üzerinde araştırma sorularına yönelik analizlerin yapılabilmesi için uygun görülmüştür.

Tablo 1: Değişkenlerin Betimsel İstatistikleri

\begin{tabular}{|l|l|l|l|l|l|l|}
\hline & Min. & Max. & $\overline{\mathbf{x}}$ & SS & Çarpıklık & Basıklık \\
\hline İletişim amaçlı & 7.00 & 35.00 & 23.859 & 5.819 & -.283 & .211 \\
\hline Tanıma ve tanınma amaçlı & 3.00 & 15.00 & 7.780 & 3.102 & .325 & -.370 \\
\hline Eğitim amaçlı & 4.00 & 20.00 & 12.243 & 3.987 & -.011 & -.529 \\
\hline Paylaşım & 9.00 & 45.00 & 27.460 & 7.723 & .046 & .156 \\
\hline Beğeni & 6.00 & 30.00 & 16.935 & 5.783 & .222 & -.230 \\
\hline Gizlilik & 5.00 & 25.00 & 11.164 & 4.842 & .791 & .220 \\
\hline Güvenlik & 3.00 & 15.00 & 8.631 & 3.021 & .075 & -.436 \\
\hline Onay Bağımlılığ1 & 15.00 & 75.00 & 41.651 & 14.683 & .245 & -.603 \\
\hline
\end{tabular}

Araştırmanın "Sanal kimlik özelliği, sosyal ağ kullanım amacı ve onay bağımlılığı cinsiyete göre farklılaşmakta mıdır?" sorusunu yanıtlayabilmek için üç ayrı bağımsız örneklemler t testi yapılmıştır.

Cinsiyet değişkeni üzerinde Sanal Kimlik Profilleri Ölçeği'nin dört alt boyutuna ilişkin analiz gerçekleştirildiğinden Bonferonni düzeltmesiyle anlamlılık değeri 0.0125 olarak alınmıştır ( $\mathrm{p}=0.05 / 4=0.0125$ ). Sosyal Ağ Siteleri Kullanım Amacı Ölçeği'nin üç alt boyutu olduğundan anlamlılık değeri $0.017(\mathrm{p}=0.05 / 3=0.017)$ olarak alınmıştır. Katılımcıların sanal kimlik profili, sosyal ağ kullanım amacı ve onay bağımlılı̆̆ının cinsiyete göre farklılaşma durumları Tablo 2'de yer almaktadır. 
Tablo 2. Sanal Kimlik Profilleri, Sosyal Ağ Kullanım Amacı ve Onay Bağımlıı̆̆ının Cinsiyete Göre Farklılașma Durumları

\begin{tabular}{|c|c|c|c|c|c|c|c|c|}
\hline & Cinsiyet & $\mathbf{N}$ & $\bar{x}$ & Ss & $\mathbf{t}$ & Sd & $\mathbf{p}$ & $\eta^{2}$ \\
\hline \multirow{2}{*}{ Paylaşım } & Kadın & 240 & 26.80 & 6.30 & \multirow{2}{*}{-1.83} & \multirow{2}{*}{574.40} & \multirow{2}{*}{.068} & \multirow{2}{*}{.005} \\
\hline & Erkek & 337 & 27.93 & 8.57 & & & & \\
\hline \multirow{2}{*}{ Beğeni } & Kadın & 240 & 16.09 & 5.23 & \multirow{2}{*}{-2.99} & \multirow{2}{*}{575} & \multirow{2}{*}{$.003 *$} & \multirow{2}{*}{.015} \\
\hline & Erkek & 337 & 17.54 & 6.08 & & & & \\
\hline \multirow{2}{*}{ Gizlilik } & Kadın & 240 & 9.70 & 4.07 & \multirow{2}{*}{-6.55} & \multirow{2}{*}{566.90} & \multirow{2}{*}{$.000^{*}$} & \multirow{2}{*}{.065} \\
\hline & Erkek & 337 & 12.20 & 5.08 & & & & \\
\hline \multirow{2}{*}{ Güvenlik } & Kadın & 240 & 9.04 & 2.93 & \multirow{2}{*}{2.77} & \multirow{2}{*}{575} & \multirow{2}{*}{$.006^{*}$} & \multirow{2}{*}{.013} \\
\hline & Erkek & 337 & 8.334 & 3.06 & & & & \\
\hline \multirow{2}{*}{ İletişim amaçlı } & Kadın & 240 & 24.65 & 5.18 & \multirow{2}{*}{2.87} & \multirow{2}{*}{559.92} & \multirow{2}{*}{$.004 *$} & \multirow{2}{*}{.013} \\
\hline & Erkek & 337 & 23.29 & 6.18 & & & & \\
\hline \multirow{2}{*}{$\begin{array}{c}\text { Tanıma ve } \\
\text { tanınma amaçlı }\end{array}$} & Kadın & 240 & 7.23 & 2.72 & \multirow{2}{*}{-3.78} & \multirow{2}{*}{562.72} & \multirow{2}{*}{$.000^{*}$} & \multirow{2}{*}{.023} \\
\hline & Erkek & 337 & 8.18 & 3.30 & & & & \\
\hline \multirow{2}{*}{ Eğitim amaçlı } & Kadın & 240 & 13.68 & 3.56 & \multirow{2}{*}{7.68} & \multirow{2}{*}{575} & \multirow{2}{*}{$.000 *$} & \multirow{2}{*}{.093} \\
\hline & Erkek & 337 & 11.22 & 3.97 & & & & \\
\hline \multirow{2}{*}{$\begin{array}{c}\text { Onay } \\
\text { Bağımlılı̆g }\end{array}$} & Kadın & 240 & 35.79 & 14.74 & 842 & 47757 & $000 *$ & 114 \\
\hline & Erkek & 337 & 45.82 & 13.15 & -0.42 & (1) & .000 & .114 \\
\hline
\end{tabular}

Sanal Kimlik Profilleri değişkeninin alt boyutlarının cinsiyete göre farklılaşma durumları incelendiğinde; Beğeni $\left(\mathrm{t}_{(575)}=-2.99 ; \mathrm{p}<.0125 ; \eta^{2}=.015\right.$. $)$ ve Gizlilik $\left(\mathrm{t}_{(567)}=\right.$ $\left.-6.55 ; \mathrm{p}<.0125 ; \eta^{2}=.065\right)$ puanlarının erkeklerin lehine anlamlı şekilde farklılaştığ 1 , Güvenlik puanının ise kadınların lehine anlamlı şekilde farklılaştığı görülmektedir $\left(\mathrm{t}_{(575)}=\right.$ $\left.2.77 ; \mathrm{p}<.0125 ; \eta^{2}=.013\right)$.

Sosyal Ăg Siteleri Kullanım Amacı'nın alt boyutlarının cinsiyete göre farklılaşma durumları incelendiğinde; Iletişim amaçlı $\left(\mathrm{t}_{(560)}=-2.87 ; \mathrm{p}<.017 ; \eta^{2}=.013\right)$ ve Ĕgitim amaçlı $\left(\mathrm{t}_{(575)}=7.68 ; \mathrm{p}<.017 ; \eta^{2}=.093\right)$ sosyal ağ kullanımında kadınların lehine, Tanıma ve tanınma amaçlı sosyal ağ kullanım puanlarının ise erkeklerin lehine anlamlı şekilde farklılaştığ 1 görülmektedir $\left(\mathrm{t}_{(563)}=-3.78 ; \mathrm{p}<.017 ; \eta^{2}=.023\right)$.

Katılımcıların Onay Bă̆ımlılı̆̆l toplam puanları incelendiğinde erkeklerin lehine anlamlı şekilde farklılaştığ görülmektedir $\left(\mathrm{t}_{(478)}=-8.42 ; \mathrm{p}<.05 ; \eta^{2}=.114\right)$. Değişskenlerin cinsiyetlere göre farklılaşmasında etki büyüklükleri; Gizlilik, Onay Bă̆ımlılığı ve Ĕgitim amaçlı sosyal ağ kullanımı Huck'a (2012) göre .06 ile .14 aralığında olduğundan orta düzeyde etki büyüklüğüne sahiptir. Diğer değişkenlerin cinsiyete göre farklılıklarında ise etki büyüklüğü değerleri .06'nın altında olduğundan düşük düzeyde etki büyüklüğüne sahiptir.

Araştırmanın "Sosyal ăg kullanım amacı, onay bağımlılığı, sanal kimlik özelliği; yaş ile nasıl bir ilişki göstermektedir?” sorusunu yanıtlayabilmek için basit korelasyon 
analizi yapılmıştır. Değişkenler arasındaki ilişkilerin incelenmesinde korelasyon değeri 0-0.30 düşük, $0.30-0.70$ orta ve 0.70 ile 1 arası ise yüksek düzeyde ilişkiyi göstermektedir (Büyüköztürk, 2012). Tablo 3'te analize yönelik bulgular yer almaktadır.

Tablo 3: Sosyal Ağ Kullanım Amacı, Onay Bağımlılığı, Sanal Kimlik Özelliği ve Yaş Arasındaki İlişkiler

\begin{tabular}{|c|c|c|c|c|c|c|c|c|}
\hline & 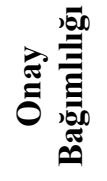 & E & ص & 产 & है & . & 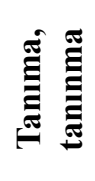 & 四 \\
\hline Yaş & $.266^{* *}$ & $.104^{*}$ & .042 & -.034 & $-.136^{* *}$ & .057 & $.098^{*}$ & $-.181^{* *}$ \\
\hline $\begin{array}{l}\text { Onay } \\
\text { Bağımlılı̆̆ } 1\end{array}$ & - & $.216^{* *}$ & $.203^{* *}$ & $.277^{* *}$ & .043 & $.086^{*}$ & $.178^{* *}$ & $-.105^{*}$ \\
\hline Paylaşım & & - & $.695^{* *}$ & $.462^{* *}$ & $.217^{* *}$ & $.629^{* *}$ & $.596^{* *}$ & $.430^{* *}$ \\
\hline Beğeni & & & - & $.529^{* *}$ & $.292^{* *}$ & $.436^{* *}$ & $.505^{* *}$ & $.343^{* *}$ \\
\hline Gizlilik & & & & - & $.373^{* *}$ & $.210^{* *}$ & $.478^{* *}$ & $.229^{* *}$ \\
\hline Güvenlik & & & & & - & $.267^{* *}$ & $.170^{* *}$ & $.374^{* *}$ \\
\hline İletişim & & & & & & - & $.504^{* *}$ & $.626^{* *}$ \\
\hline $\begin{array}{l}\text { Tanıma, } \\
\text { tanınma }\end{array}$ & & & & & & & - & $.436^{* *}$ \\
\hline
\end{tabular}

$* \mathrm{p}<0.05, * * \mathrm{p}<0.001$

Tablo 3'e göre yaş ve Onay Bağımlığı'nın diğer değişkenler ile arasında düşük düzeyde ilişki bulunmaktadır. Paylaşım ve Beğeni değişkenleri ile Gizlilik, İletişim amaçlı, Tanıma ve tanınma amaçlı ve Eğitim amaçlı sosyal ağ kullanımı ile orta düzeyde pozitif yönde anlamlı ilişki bulunmaktadır. Paylaşım ve Beğeni değişkenleri ile Güvenlik arasında ise pozitif yönde ve düşük düzeyde anlamlı ilişki bulunmaktadır. Gizlilik değişkeni ile Tanıma ve tanınma amaçlı sosyal ağları kullanım, Paylaşım, Beğeni ve Güvenlik değişskenleri arasında orta düzeyde pozitif yönde anlamlı; Onay Bağımlılığı, İletişim ve Eğitim amaçlı sosyal ağ kullanımı ile düşük düzeyde pozitif yönde anlamlı ilişkisi vardır. Güvenlik ile Gizlilik ve Eğitim amaçlı sosyal ağ kullanımı arasında orta düzeyde pozitif yönde anlamlı ilişki bulunurken diğer değişkenler ile düşük düzeyde ilişkisi bulunmaktadır. İletişim amaçlı sosyal ağ kullanımı ile Paylaşım, Beğeni, Tanıma ve tanınma amaçlı ve Eğitim amaçlı kullanım arasında orta düzeyde pozitif yönde anlamlı ilişki bulunurken diğer değişkenlerle düşük düzeyde pozitif yönlü ilişkisi bulunmaktadır. Tanıma ve tanınma amaçlı sosyal ağ kullanımının Paylaşım, Beğeni, Gizlilik, İletişim amaçlı ve Eğitim amaçlı sosyal ağ kullanımı ile orta düzeyde pozitif yönde anlamlı ilişkisi bulurken diğer değişkenlerle düşük düzeyde pozitif yönde ilişkisi bulunmaktadır. Eğitim amaçlı sosyal ağ kullanımının ise; Paylaşım, Beğeni, Güvenlik, İletişim amaçlı ve Tanıma tanınma amaçlı sosyal ağ kullanımı ile orta düzeyde pozitif yönde anlamlı ilişkisi bulunurken diğer değişkenlerle düşük düzeyde ilişkisi bulunmaktadır.

Araştırmanın "Sosyal ağ kullanım amaçları ve onay bağımlılığı sanal kimlik özelliğini açıklamakta mıdır?” sorusunu yanıtlayabilmek için standart çoklu regresyon 
analizi tekniği kullanılmıştır. Bu analizin ön şartları incelenerek ve uygun bulunduğundan analiz sonuçları Tablo 4'te gösterilmiştir.

Tablo 4: Sanal Kimlik Profilinin Açıklanma Düzeyi

\begin{tabular}{|c|c|c|c|c|c|c|c|c|}
\hline Model & $\begin{array}{c}\text { Yordayan } \\
\text { Değişkenler }\end{array}$ & B & $\begin{array}{l}\text { Std. } \\
\text { Hata }_{B}\end{array}$ & $\boldsymbol{\beta}$ & $\mathbf{t}$ & $\mathbf{p}<$ & $\begin{array}{c}\text { İkili } \\
\text { r }\end{array}$ & $\begin{array}{c}\text { Kismi } \\
\mathbf{r}\end{array}$ \\
\hline \multirow{5}{*}{1} & Sabit & 14.802 & 2.541 & & 5.824 & $.000^{*}$ & & \\
\hline & Onay Bağımlılığ & 206 & .036 & 180 & 5.733 & $.000^{*}$ & .256 & .233 \\
\hline & İletişim amaçlı & .695 & .119 & 240 & 5.863 & $.000^{*}$ & .547 & .238 \\
\hline & $\begin{array}{l}\text { Tanıma ve } \\
\text { tanınma amaçlı }\end{array}$ & 2.168 & .195 & .400 & 11.109 & $.000^{*}$ & .615 & .421 \\
\hline & Eğitim amaçlı & .602 & 170 & 143 & 3.547 & $.000^{*}$ & .449 & .147 \\
\hline
\end{tabular}

Onay Bağımlılı̆̆ı, Tanıma ve tanınma amaçlı, İletişim amaçlı ve Eğitim amaçlı kullanım değişkenleri; Sanal Kimlik Profili ile anlamlı bir ilişki içerisindedir $(\mathrm{R}=0.698, \mathrm{R} 2=0.487, \mathrm{p}<.01)$. Söz konusu dört yordayıcı değişkenin Sanal Kimlik Profili'ndeki toplam varyansın \%49'unu açıkladığı görülmektedir. Standardize edilmiş regresyon katsayısına göre $(\beta)$, yordayıcı değişkenlerin Sanal Kimlik Profili üzerindeki önem sırası; Tanıma ve tanınma amaçlı kullanım $(\beta=0.400)$, İletişim amaçlı kullanım $(\beta=0.240)$, Onay Bağımlılığı $(\beta=0.180)$ ve Eğitim amaçlı kullanım $(\beta=0.143)$ şeklindedir. Regresyon katsayılarının anlamlılığına ilişkin $t$ testi sonuçları incelendiğinde ise, tüm değişkenlerin yordanan değişken üzerinde anlamlı birer yordayıcı olduğu görülmektedir $(p<0.01)$. Yordayıcı değişkenlerle Sanal Kimlik Profili arasındaki ilişkilere bakıldığında; Onay Bağımlılığı ile ( $\mathrm{r}=0.256)$ (diğer yordayıcı değişkenlerin etkisi kontrol edildiğinde $\mathrm{r}=0.233$ ), İletişim amaçlı kullanım ile $(\mathrm{r}=0.547)$ (diğer yordayıcı değişkenlerin etkisi kontrol edildiğinde $\mathrm{r}=0.238$ ), Tanıma ve tanınma amaçlı kullanım ile $(\mathrm{r}=0.615)$ (diğer yordayıcı değişkenlerin etkisi kontrol edildiğinde $r=0.421$ ), Eğitim amaçlı kullanım ile $(\mathrm{r}=0.449)$ (diğer yordayıc1 değişkenlerin etkisi kontrol edildiğinde $\mathrm{r}=0.147$ ) düzeyinde korelasyon gözlenmektedir. Regresyon analizi sonuçlarına göre, Sanal Kimlik Profili'nin yordanmasına ilişkin regresyon eşitliği matematiksel modeli aşağıda verilmiştir.

Sanal Kimlik Profili $=14.802+(2.168 \times$ Tanıma ve Tanınma Amaçlı Kullanım $)+$ $(0.695$ x İletişim Amaçlı Kullanım $)+(0.602$ x Eğitim amaçlı Kullanım $)+(0.206$ x Onay Bağımlılı̆̆ı)

\section{Tartışma ve Sonuç}

Günümüzde teknolojik araçlara sahip olma ve bu araçları iletişim amaçlı kullanma oranı hızla artmaktadır. İnternet teknolojilerinin öncü uygulamalarından olan sosyal ağlar 
da benzer bir şekilde kullanımı hızla artan ortamlardır (Kang ve Schuett, 2013). Araştırma sonuçlarına göre sosyal ağ kullanım oranları ortalamanın üzerinde bulunurken, kullanım amaçlarında iletişimin öne çıktığı görülmektedir. Dolayısıyla ortamın gerçek ya da sanal olmasına bakılmaksızın bireyler genellikle iletişim gereksinimini karşılama eğilimindedir. Sosyal ağ uygulamalarının kullanıcı beklentilerini karşılama oranı arttıkça kullanım oranlarında da önemli bir artış yaşanmıştır. 2020'den 2021'e dünya çapındaki aktif sosyal ağ kullanıcı sayısı yılık \%13.2 artışla 4.20 milyara ulaşmıştır (Global Digital Report, 2021). Kullanım oranlarına yönelik bu istatistiklerde, sosyal ağların kullanım amaçlarının gelişip çeşitlenmesinin önemli bir etkisi olduğu düşünülmektedir. İnternet kullanıcılarının büyük çoğunluğunun sosyal ağ kullandığ 1 göz önüne alındığında ortalamanın üzerinde bir sosyal ağ kullanımından söz edilebilir. Buna göre bu araştırmanın ilk bulgularından olan tüm değişkenlere (Sosyal Ăg Kullanım Amac1, Sanal Kimlik Profilleri ve Onay Bağımlılığı) ait ortalama toplam puanlarının ortalamanın üzerinde olması dünyadaki sosyal ağ kullanım oranlarını destekler niteliktedir. Sosyal ağların kullanım amaçlarına bakıldığında en yoğun kullanımın iletişim amaçlı kullanım olduğu görülmektedir. İletişim araçları çoğalırken sosyal ağların iletişimi kolaylaştırması ve her an erişilebilir konumda bulunması sosyal ağların bu yönde kullanımını desteklediği düşünülmektedir. Sanal Kimlik Profilleri'nin alt boyutları incelendiğinde ise katılımcıların paylaşıma daha çok önem verdiği görülmektedir. Sosyal ağlar doğaları gereği etkileşim gerektiren ortamlardır. Kullanıcılar paylaşım yaparak ya da yapılan paylaşımlara etkileşimde bulunarak bu ortamları kullanırlar. Dolayısıyla sosyal ağ kullananların paylaşımda bulunmaları doğal bir sonuç olarak değerlendirilmektedir.

Sosyal ağ sitelerinde mahremiyet ve gizlilik; kişisel bilgilerin üçüncü kişilerce ele geçirilmesini önlemek ve ikili iletişimlerde kişisel bilgilerin paylaşılmasında dikkatli davranılmasını gerektiren önemli bir konu olarak görülmektedir(Ellison vd., 2011). Sosyal ağların kullanımında gizliliğe ilişkin çalışmalara bakıldığında kadınların mahremiyet konusunda daha endişeli olmalarına rağmen gizlilik göstergelerinde erkekler ile kadınlar arasında bir farklılık olmadığ 1 belirtilmiştir (Fogel ve Nehmad, 2008; Mohamed ve Ahmad, 2012). Alanyazındaki bu bulguların tersine bu araştırmada ise erkeklerin sosyal ağlarda sanal kimliklerinde gizlilik boyutuna daha çok dikkat ettiği görülmüştür. Sosyal ağlardaki güvenlik boyutuna ise daha çok kadınların önem verdiği görülmüştür. $\mathrm{Bu}$ durumun, kadınların mahremiyet konusunda erkeklere göre daha endişeli olmalarının sonucu olarak, koruma içgüdüsüyle hareket etmelerinden kaynaklanmış olabileceği düşünülmektedir. Cinsiyetin etkide bulunduğu alanlardan biri de sosyal ağ kullanım amacıdır. Alanyazında genel olarak erkeklerin sosyal ağları daha çok arkadaş edinmek, tanımak ve tanınmak amaçlı kullandığ 1 (Aydın, 2016; Koçer, 2012), kadınların ise daha çok akademik, ödev, proje gibi Eğitim amaçlı olarak kullandığı (Aydın, 2016; Mazman ve Usluel, 2011), aynı zamanda kadınların İletişim amaçlı olarak sosyal ağları daha çok kullandığ1(Muscanell ve Guadagno, 2012; Williams vd., 2009) görülmüştür. Alanyazındaki bu bulgular bu araştırmadaki cinsiyete göre sosyal ağ kullanımına ilişkin bulguları desteklemektedir. Bireyler sanal dünyada varlık gösterebilmek adına paylaşım yapmaya önem verirler. Aynı zamanda bu paylaşımların diğer bireyler tarafından onaylanmasına yönelik önemli bir beklenti söz konusudur. Cinsiyete göre Onay Bağımlılığı puanları incelendiğinde erkeklerin daha fazla onaylanma isteğinde bulunduğu görülmüştür. Cesur 
ve Dil'in (2018) benlik algısı üzerinde yaptığı çalışmada sosyal ağları kullanan erkeklerin daha yüksek benlik algısına sahip olduğu ve sosyal ağlarda kendilerini oldukları gibi gösterdikleri belirtilmektedir. Bunun tersine bu araştırmadaki erkek katılımcıların Onay Bağımlılığg puanlarının kadınlara göre anlamlı şekilde farklılaşması ise erkeklerin benlik sunumunda çevreleri tarafından nasıl algılandıklarının önemli olduğu yani benlik algıları ve sunumunda çevrelerinden gelen dönütlere göre hareket ettikleri değerlendirmesi yapılabilir. Dolayısıyla elde edilen bulgulara göre sanılanın aksine kadınlardan çok erkeklerin kabul edilme ve onaylanma eğiliminde olduğu görülmektedir.

$\mathrm{Bu}$ araştırmada ayrıca katılımcıların yaşları ile diğer değişkenler arasındaki ilişkiler de incelenmiştir. Yetişme şekli ve yaşanılan ortam farklılıkları sebebiyle yaşamın farklı dönemlerinde farklı yaşantılar gerçekleştiren bireylerin beklentilerinin, karakterlerinin, beğeni ve isteklerinin de farklılaşacağı, bu doğrultuda sosyal ağları kullanma amaçlarının, onay beklentilerinin ve Sanal Kimlik Profillerine yönelik tercihlerinin de farklılaşacağ düşünülebilir. Öyle ki sosyal ağların yaşa, yaşantıya veya kuşaklara göre kullanımına yönelik alanyazında pek çok araştırma yer almaktadır (Bandilli, 2015; Okumuş ve Parlar, 2018; Ramasubbu, 2016). Sosyal ağ kullanımına yönelik yaş ve kuşak arasında ilişki bulunması beklentilerine karşılık bu araştırma bulgularında yaş ile Sosyal A $\breve{g}$ Kullanım Amacı boyutları, Sanal Kimlik Profili ve Onay Bağımlılığı arasında düşük düzeyde ilişsiler görülmüştür. Yaş arttıkça sosyal ağların Eğitim amaçlı kullanımının ve Sanal Kimlik'lerinde güvenliğe önemin anlamlı şekilde azaldığı görülmüştür. Araştırma katılımcılarının 18-60 yaş aralığında olduğu düşünüldüğünde lisans ve lisansüstü eğitimden sonra sosyal ağların eğitim amaçlı kullanımının azalması doğal görülmektedir. Ancak diğer taraftan bu bulgu, sosyal ağların yaşam boyu öğrenme bağlamındaki rolünü de sorgular bir sonuç olarak değerlendirilebilir. Eğitim amaçlı kullanımın yaş arttıkça azalmasının yanı sıra, yaşla birlikte tanınmak için sosyal ağ kullanımının, paylaşımın ve onaylanma bağımlılığının anlamlı şekilde arttığı da görülmüştür. Buna göre yaşları artan bireyler için çevredekiler tarafından kabul edilme, onaylanma ve tanınma isteğinin arttığı ve bunun sonucu olarak bireylerin paylaşım yapmaya yöneldikleri ifade edilebilir. Özellikle sosyal ağların başlangıçtaki genç kullanıcı kesimi yerine daha geniş bir yaş aralığında kullanılıyor oluşu bu bulguyu desteklemektedir. Geniş bir yaş grubu tarafından sosyal ağların kullanılması Global Digital 2021 raporundan da görülebilmektedir. Araştırmanın diğer sonuçlarına göre Sosyal Ağ Kullanım Amaçları, Onay Bağımlılığı ve Sanal Kimlik Profilleri'nin birbiriyle orta düzeyde anlamlı ilişkilere sahip olduğu görülmektedir. Bu ilişkiler alanyazında Sosyal A ̆g Kullanım Amacı, kullanıcı profilleri, sosyal ağlarda oluşturulan kimlikler ve davranışlar üzerine yapılan çalışmalarla benzerlik göstermektedir (Goffman, 2016; Fiske, 2003; Nilan ve Feixa, 2006).

Sanal Kimlik Profili'nin açıklanmasına ilişkin araştırma sonuçları incelendiğinde sosyal ağların Tanıma ve tanınma, İletişim, Eğitim amaçlı kullanımı ve Onay Bağımlılı̆̆ Sanal Kimlik Profili'ni \%49 oranında açıklamaktadır. Değişkenlerin açıklama oranları incelendiğinde Sanal Kimliği en yüksek oranda Tanıma ve tanınma amaçlı sosyal ağ kullanımının açıkladığı görülmüştür. Bireylerin kendilerini tanıtma amaçlı olarak birer kimlik oluşturduğu düşünüldüğünde, Sanal Kimliğin açıklanmasında Tanıma ve tanınma amaçlı kullanımının beklendik bir durum olduğu söylenebilir. Sanal Kimliğin 
açıklanmasında önem sırası Tanıma ve tanınma amaçlı, İletişim amaçlı olarak kullanım, Onay Bağımlılı̆̆ı ve Eğitim amaçlı kullanım şeklinde belirlenmiştir. Sanal Kimliğin açıklayıcı değişkenlerle olan ilişkisine bakıldığında Sosyal A ̆g Kullanım Amacı boyutlarının hepsiyle orta düzeyde anlamlı ilişki bulunurken, diğer değişkenlerin etkisi ortadan kaldırıldığında İletişim ve Eğitim amaçlı sosyal ağ kullanımının Sanal Kimlik ile düşük düzeyde ilişkili olduğu görülmüştür. Sanal kimliklerin oluşturulmasında Tanıma ve tanınma amaçlı kullanım öncelikli olarak birincil etken durumundayken, İletişim ve Eğitim amaçlı sosyal ağ kullanımı ve Onay Bağımlılığı daha az belirleyici durumdadır. Araştırmanın tüm sonuçları ele alındığında sosyal ağlardaki sanal kimliklerin belirleyici özelliklerini ortaya çıkarmada alanyazına önemli katkı sağlandığı ifade edilebilir. İleride yapılacak çalışmalarda ise sanal kimliğin diğer çevresel ve psikolojik boyutlarına ilişkin özellikle deneysel araştırmalar yapılması önerilmektedir.

\section{Kaynaklar}

Arklan, Ü. (2016). "Sosyal Medyanın Siyasal Amaçlı Kullanımı: A ̆g Kuşağının Kullanım Alışkanlıkları Üzerine Bir Araştırma”, Gümüşhane Üniversitesi İletişim Fakültesi Elektronik Dergisi, 4(2), s.618-657.

Atıcı, B. ve Çevik Polat, Ö. (2010). Sosyal Ağların İlköğretim Öğrencilerinin Başarısı ve Öğrenme Ortamı Tercihine Etkisi. IETC, İstanbul, TURKEY.

Aydın, İ. E. (2016). “Üniversite Öğrencilerinin Sosyal Medya Kullanımları Üzerine Bir Araştırma: Anadolu Üniversitesi Örneğì”, Selçuk Üniversitesi Sosyal Bilimler Enstitüsü Dergisi, 35, s.373-386.

Bandilli, M. (2015). Generation Y, Technology And Our Strive For Success. Https://Futurelabeurope.Eu/2015/09/07/Generationy-Technology-And-Our-Strive-ForSuccess/,15.11.2016 adresinden erişilmiştir.

Barut Tuğtekin, E. ve Dursun, Ö. Ö. (2020). "Examining Virtual İdentity Profiles Of Social Network Users With Respect To Certain Variables", Pegem Eğitim ve Öğretim Dergisi, 10(2), s.427-464.

Benson, V., Saridakis, G. and Tennakoon, H. (2015). "Purpose Of Social Networking Use And Victimisation: Are There Any Differences Between University Students And Those Not in HE?", Computers in Human Behavior, 51, s.867-872.

Brandtzæg, P. B. \& Heim, J. (2009). Why People Use Social Networking Sites. Proceedings Of The HCI International 2009. Springer-Verlag Berlin Heidelberg, s.143152.

Burns D. (2006). İyi Hissetmek, Karaosmanoğlu, H.A. (Çev.). Dördüncü Bask1, İstanbul, Psikonet Yayınları.

Büyüköztürk, Ş. (2012). Sosyal Bilimler İçin Veri Analizi El Kitabı (16. Baskı). Ankara: Pegem Akademi Yayıncılık. 
Cesur, A. ve Dil, K. (2018). "Üniversite Öğrencilerinin Sosyal Medyada Benlik Sunumları ve Yansımaları: Çankırı Karatekin Üniversitesi Örneği”, Avrasya Sosyal ve Ekonomi Araştırmaları Dergisi, 5(7), s.13-32.

Çetin, E. (2009). Sosyal İletişim Ağları ve Gençlik: Facebook Örneği. Proceedings of International Davraz Congress, s.1094-1105. Http://Idc.Sdu.Edu.Tr/Tammetinler/ Bilim/Bilim15.Pdf adresinden erişilmiştir.

Çiftçi, H. (2018). “Üniversite Öğrencilerinde Sosyal Medya Bağımlılığı”, MANAS Sosyal Araştırmalar Dergisi, 7(4), s.417-434.

Çokluk, Ö., Şekercioğlu, G. Ve Büyüköztürk, Ş. (2012). Sosyal Bilimler İçin Çok Değişkenli İstatistik: SPSS ve LISREL Iygulamaları. Pegem Akademi.

Dursun, Ö. Ö. ve Barut, E. (2016). Sosyal Medyanın Yeni Sorunsalı: Sanal Kimlikler. Eğitim Teknolojileri Okumaları 2016 (Eds: Aytekin İşman, Hatice Ferhan Odabaşı, Buket Akkoyunlu). Salmat Basım Yayıncılık.

Ellison, N. B., Vitak, J., Steinfield, C., Gray, R. and Lampe, C. (2011). "Negotiating Privacy Concerns And Social Capital Needs in A Social Media Environment", In Privacy Online, 19-32. Springer Berlin Heidelberg. ve Sanat.

Fiske, J. (2003). İletişim Çalışmalarına Giriş, Süleyman İrvan (Çev.), Ankara: Bilim

Fogel, J. and Nehmad, E. (2009). "Internet Social Network Communities: Risk Taking, Trust, And Privacy Concerns", Computers in Human Behavior, 25(1), s.153-160.

Fraenkel, J. R., Wallen, N. E. and Hyun, H. (2012). How To Design And Evaluate Research in Education (8. Ed.). New York: Mcgraw-Hill Humanities/Social Sciences/ Languages.

Global Digital Report (2021). Digital in 2021. Https://Wearesocial.Com/ Digital-2021 adresinden erişilmiştir.

Goffman, E. (2016). Günlük Yaşamda Benliğin Sunumu (3.Ed.). İstanbul: Metis Yayınc1lik.

Himmetoğlu, A. ve Ayhan, A. (2021). "Sosyal Medya Kullanım Motivasyonu, Boş Zaman Doyumu ve Yaşam Doyumu Arasındaki İlişkinin İncelenmesi: Akdeniz Üniversitesi Örneği”, Mehmet Akif Ersoy Üniversitesi İktisadi ve İdari Bilimler Fakültesi Dergisi, 8(2), s.1141-1174.

Huck, S. W. (2012). Reading Statistics And Resarch (6.Ed.). Boston: Pearson.

İmamoğlu, S. E. ve Aydın, B. (2009). “Kişilerarası İlişki Boyutları Ölçeğinin Geliştirilmesi”, Studies in Psychology, 29, s.39-64.

Kang, M. and Schuett, M. A. (2013). "Determinants Of Sharing Travel Experiences in Social Media", Journal Of Travel \& Tourism Marketing, 30(1-2), s.93-107. 
Karal, H. ve Kokoç, M. (2010). "Üniversite Öğrencilerinin Sosyal Ă̆ Siteleri Kullanım Amaçlarını Belirlemeye Yönelik Bir Ölçek Geliştirme Çalışması”, Turkish Journal Of Computer And Mathematics Education, 1(3), s.251-263.

Karaşar, B. ve Öğülmüş, S. (2016). "Sosyal Onay İhtiyacı Ölçeği: Geçerlik ve Güvenirlik Analizi”, Ege Eğitim Dergisi, 17(1), s.84-104.

Karlı, İ. (2010). Medya Kuruluşları Sosyal Paylaşım Ağlarını Neden Kullanır? II. International Coference Of New Media And Interactivity, İstanbul.

Koçer, M. (2012). "Erciyes Üniversitesi Öğrencilerinin İnternet ve Sosyal Medya Kullanım Alışkanlıkları”, Akdeniz Üniversitesi İletişim Fakültesi Dergisi, (18), s.70-85.

Leskovec, J., Huttenlocher, D. and Kleinberg, J. (2010). Predicting Positive And Negative Links in Online Social Networks. In Proceedings Of The 19th International Conference On World Wide Web, s.641-650.

Loreti, P., Bracciale, L. and Caponi, A. (2018). "Push Attack: Binding Virtual And Real Identities Using Mobile Push Notifications”, Future Internet, 10(2), 13, s.1-17.

Maslow, A. H. (1943). “A Theory Of Human Motivation”, Psychological Review, 50(4), s.370-396.

Mazman, S. G. and Usluel, Y. K. (2011). "Gender Differences in Using Social Networks", Turkish Online Journal Of Educational Technology-TOJET, 10(2), s.133-139.

Mohamed, N. and Ahmad, I.H. (2012). "Information Privacy Concerns, Antecedents And Privacy Measure Use in Social Networking Sites: Evidence From Malaysia", Computers in Human Behaviour, 28, s.2366-2375.

Muscanell, N. L. and Guadagno, R. E. (2012). "Make New Friends Or Keep The Old: Gender And Personality Differences in Social Networking Use", Computers in Human Behavior, 28(1), s.107-112. Routledge

Nilan, p., Feixa, C. (2006). Global Youth? Hybrid Identities, Plural Worlds. London:

Okumuş, V. ve Parlar, H. (2018). "Çocukların Sosyal Medya Kullanım Amaçları ve Ebeveyn Tutumları”, İstanbul Ticaret Üniversitesi Sosyal Bilimler Dergisi, 17(33), s.357-368.

Özdemir, S. S., Özdemir, M., Polat, E. ve Aksoy, R. (2014). "Sosyal Medya Kavramı ve Sosyal Ağ Sitelerinde Yer Alan Online Reklam Uygulamalarının İncelenmesi”, Electronic Journal Of Vocational Colleges. Www.Ejovoc.Org/Makaleler/Aralik_2014/ Pdf/06.Pdf adresinden erişilmiştir.

Pallant, J. (2007). SPSS Survival Manual: A Step By Step Guite To Data Analysis Using SPSS Version 15. (Third Edition). New York: Open Universty Press.

Parveen, F., Jaafar, N. I. and Ainin, S. (2015). "Social Media Usage And Organizational Performance: Reflections Of Malaysian Social Media Managers", Telematics And Informatics, 32(1), s.67-78. 
Ramasubbu, S. (2016). From Gen X To Y And Z: Technology And The Generation Gap. Http://Www.Huffingtonpost.Com/Surenramasubbu/From-Gen-X-To-Y-AndZtec_B_7645410.Html adresinden erişilmiştir.

Tabachnick, B. G. and Fidell, L. S. (2007). Using Multivariate Statistics. Allyn \& Bacon/Pearson Education.

Tugtekin, U., Barut Tugtekin, E., Kurt, A. A. and Demir, K. (2020). "Associations Between Fear Of Missing Out, Problematic Smartphone Use, And Social Networking Services Fatigue Among Young Adults", Social Media+ Society, 6(4), s.1-17.

Usluel, Y.K., Demir, Ö. ve Çınar, M. (2014). "Sosyal Ağların Kullanım Amaçları Ölçeği”, Eğitim Teknolojileri Araştırma Dergisi, 5(2).

Williams, D., Consalvo, M., Caplan, S. and Yee, N. (2009). "Looking For Gender (LFG): Gender Roles And Behaviors Among Online Gamers", Journal Of Communication, 59, s. 700-725.

Yaman, Z. ve Kavuncu, B. (2019). “Üniversite Öğrencilerinin Sosyal Gelişmeleri Kaçırma Korkusunun ve Sosyal Ağ Kullanım Amacının NOMOFOBİ Düzeyine Etkisi”, Sosyal Bilimler Araştırmaları Dergisi, 14(2), s.555-570.

Araştırmacı Katkı Oranı: Araştırmacılar çalışmaya eşit oranda katkı sunmuştur.

Destekleyen Kurum/Kuruluşlar: Herhangi bir kurum/kuruluştan destek alınmamıştır.

Çıkar Çatışması: Herhangi bir çıkar çatışması bulunmamaktadır 